\title{
Effect of Mesorhizobium, plant growth promoting rhizobacteria and phosphorus on plant biometery and growth indices of desi chickpea (Cicer arietinum $\mathrm{L}$.
}

\author{
Zorawar Singh*1, Guriqbal Singh $^{2}$ and Navneet Aggarwal ${ }^{2}$ \\ ${ }^{1}$ Department of Agronomy, Punjab Agricultural University, Ludhiana-141 004 (Punjab), INDIA \\ ${ }^{2}$ Department of Plant Breeding and Genetics, Punjab Agricultural University, Ludhiana-141004 (Punjab), INDIA \\ *Corresponding author : E-mail - zs.dhillon@gmail.com \\ Received: September 10, 2016; Revised received: February 18, 2017; Accepted: July 13, 2017
}

\begin{abstract}
The field experiment was conducted during 2015-16 to study the effect of biofetilizer inoculation [control, Mesorhizobium only, Mesorhizobium + RB-1 (Pseudomonas argentinensis) and Mesorhizobium + RB-2 (Bacillus aryabhattai)] and four levels of phosphorus $\left(0,15,20\right.$ and $25 \mathrm{~kg} \mathrm{P}_{2} \mathrm{O}_{5}$ ha $\left.^{-1}\right)$ on chickpea growth. RB-1 and RB-2 were the plant growth promoting rhizobacteria (PGPR). Biofertilizers could play a crucial role in reducing the dependence on chemical fertilizers by fixing the atmospheric nitrogen for crop and/or by increasing the availability of phosphorus and phytohormones to the crop. The 16 treatment combinations were laid out in Factorial Randomized Complete Block Design and replicated three times. In biofertilizer treatments, Mesorhizobium + RB-1 proved superior over control and sole inoculation of Mesorhizobium and at par with Mesorhizobium + RB-2 with respect to plant height $(\mathrm{cm})$, number of branches (plant $\left.{ }^{-1}\right)$, shoot and root dry matter $\left(\mathrm{kg} \mathrm{ha}^{-1}\right)$ which were recorded at 30, 60 90, 120 days after sowing (DAS) and at harvest. Application of $25 \mathrm{~kg} \mathrm{P}_{2} \mathrm{O}_{5}$ ha ${ }^{-1}$ gave the highest values of all the growth attributes viz. plant height $(60 \mathrm{~cm})$, number of primary (5.3) and secondary (27.2) branches per plant, shoot dry matter $\left(4000 \mathrm{~kg} \mathrm{ha}^{-1}\right)$ and root dry matter $\left(354 \mathrm{~kg} \mathrm{ha}^{-1}\right)$ which were significantly higher than that of 0 and $15 \mathrm{~kg} \mathrm{P}_{2} \mathrm{O}_{5} \mathrm{ha}^{-1}$ and at par with $20 \mathrm{~kg} \mathrm{P}_{2} \mathrm{O}_{5} \mathrm{ha}^{-1}$. Similar results were observed in case of crop growth rate (CGR) whereas relative growth rate (RGR) was not influenced significantly by various biofertilizer and phosphorus treatments. The dual inoculation with PGPR strains along with phosphorus application have a supplementary effect on the growth of chickpea.
\end{abstract}

Keywords: Chickpea, growth indices, Mesorhizobium, phosphorus, shoot dry matter

\section{INTRODUCTION}

Chickpea (Cicer arietinum L.), also called Bengal Gram or garbanzo bean, is the third most widely grown cool season pulse crop in the world after common beans (Phaseolus vulgaris L.) and fieldpea (Pisum sativum L.) (Dotaniya et al., 2014). In India, chickpea is a premier pulse crop grown on area of 10.2 million ha during 2013-14, contributing 9.5 million tonnes to the national pulse basket with productivity of $967 \mathrm{~kg} \mathrm{ha}^{-1}$ (Anonymous, 2016). It holds an important role in the vegetarian diets due to its high protein content (16$20 \%)$, carbohydrates $(51 \%)$, fat $(25.8 \%)$, total dietary fibre, vitamins and minerals (Hirdyani, 2014). Chickpea is a winter season crop primarily grown in low rainfall areas. Diversified domestic, industrial and other uses of chickpea and its ability to grow better with low inputs under abrasive edaphic factors and arid environments make it an important component of the cropping system of subsistence farmers in the Indian subcontinent.

Biofertilizers are preparations containing living cells or latent cells of efficient strains of microorganisms, which when applied through seed or soil treatment, promote plant growth by increasing the nutrient acqui- sition to the host plant. These help in enhancing biological nitrogen fixation through promotion of nodule formation, phosphorus solubilisation, production of phytohormones like cytokinins, gibberellins and indole acetic acid (IAA) (Verma et al., 2013) and also show antagonism against phytopathogens by production of siderophores, celluloses and antibiotics (Kaur and Sharma, 2013, Kandoliya and Vakharia, 2013) in chickpea. Seed inoculation with Rhizobium increases the nodulation and its dry weight which is beneficial in improving the growth attributes viz. plant height, root length and root dry weight and hence improves nutrient availability (Das et al., 2013 and Shahzad et al., 2014). The Rhizobium inoculation enhances the biological nitrogen fixation of the plant which not only improves the nitrogen nutrition of inoculated chickpea but also reduces the dependence on inorganic nitrogen fertilizers (Namvar et al., 2011).

Phosphorus (P) is recognized as the second most important element in plant nutrition after nitrogen. It is a key nutrient element required for high and sustained productivity of grain legumes. $\mathrm{P}$ is involved in several plant functions including energy transfer reactions, photosynthesis, transformation of sugars and starches and nutrient translocation within the plant (Dotaniya et 
al., 2014). It stimulates root development and enhances the development of reproductive parts (Gulpadiya and Chhonkar, 2014). Increasing $P$ levels upto $40 \mathrm{~kg}$ $\mathrm{P}_{2} \mathrm{O}_{5} \mathrm{ha}^{-1}$ resulted in significant improvement in growth, yield attributes and grain yield as compared to lower doses of phosphorus (Pingoliya et al., 2014).

The response to soluble phosphorus fertilizers is very low due to rapid $\mathrm{P}$ fixation (Sarawgi et al., 2012). Moreover, phosphatic fertilizers are not only costly but also their supply is lower than their demand. Hence, it is highly desirable to explore the possibilities of saving phosphatic fertilizers without sacrificing economic yields. In these conditions, biofertilizers could play a crucial role by increasing the availability of phosphorus and other nutrients to the crops. The plant growth promoting rhizobacteria (PGPR) inoculants hold great prospects for sustaining the crop production along with balanced P fertilizer application as of PGPR with Psolubilizing ability plays an important role in improving the soil $\mathrm{P}$ availability to plants by lowering soil $\mathrm{pH}$ and microbial production of organic acids as well as mineralization of fixed phosphorus (Singh and Singh, 2014). Therefore, the experiment was conducted with the aim of improving the performance of chickpea in terms of growth attributes of chickpea in a cost effective manner, employing graded levels of inorganic $\mathrm{P}$ fertilizer along with biofertilizers.

\section{MATERIALS AND METHODS}

Experimental site: A field experiment was conducted at research farm of Pulses Section, Department of Plant Breeding and Genetics, Punjab Agricultural University, Ludhiana during the rabi 2015-16.The soil of the experimental site was loamy sand in texture with $\mathrm{pH}$ of 7.5 , low organic carbon $(0.35 \%)$ and available $\mathrm{N}$ (123.8 $\left.\mathrm{kg} \mathrm{ha}^{-1}\right)$ and medium available $\mathrm{P}\left(15.4 \mathrm{~kg} \mathrm{ha}^{-1}\right)$ and available $\mathrm{K}\left(177.5 \mathrm{~kg} \mathrm{ha}^{-1}\right)$. The meteorological data during the crop period indicated that the total amount of rainfall received during crop season was $74.0 \mathrm{~mm}$. Mean maximum and minimum air temperature was recorded to be $24.9^{\circ} \mathrm{C}$ and $11.5^{\circ} \mathrm{C}$ respectively.

Experimental design: The experiment comprised of four biofertilizer treatments [control, Mesorhizobium only, Mesorhizobium + RB-1 (Pseudomonas argentinensis) and Mesorhizobium + RB-2 (Bacillus aryabhattai)] and four levels of phosphorus $(0,15,20$ and $\left.25 \mathrm{~kg} \mathrm{P}_{2} \mathrm{O}_{5} \mathrm{ha}^{-1}\right)$. The 16 treatment combinations were laid out in randomized complete block design and replicated three times in $5.5 \mathrm{~m} \times 3 \mathrm{~m}$ plots. The chickpea cultivar 'PBG 7' was sown on 8 November 2015 at 30 $\mathrm{cm}$ row to row spacing. The seeds were inoculated with Mesorhizobium sp. ciceri (LGR-33), RB-1 (Pseudomonas argentinensis) and RB-2 (Bacillus aryabhattai), as per the treatments which were applied to the seed before sowing. Inoculated seeds were dried in the shade before sowing. RB-1 and RB-2 were plant growth promoting rhizobacteria (PGPR). The microbial cultures were procured from the Microbiology laboratory of Pulses Section, Department of Plant Breeding and Genetics, PAU, Ludhiana. After the procurement of cultures, the sub culturing was done for 15 days and stored in refrigerator at $4^{\circ} \mathrm{C}$ in aerobic conditons. Further, $\mathrm{P}$ was applied as basal dose before sowing as per the treatments.In addition, $15 \mathrm{~kg} \mathrm{~N} \mathrm{ha}^{-1}$ in the form of urea was applied in all the treatments at sowing time. The periodic data of growth attributes were taken at 30,60, 90, 120 DAS and at harvest.

Plant height: The height of five randomly selected plants from each treatment was measured from the ground surface up to the top of the main stem of plant. The initial observation was recorded at 30 DAS and then subsequently at 30 days interval till harvesting.

Number of branches: Five representative plants from each treatment were selected randomly and number of primary as well as secondary branches were counted, and then presented on plant ${ }^{-1}$ basis. These were recorded periodically at 30 days interval, starting from 60 DAS and at harvesting.

Shoot dry matter accumulation: For shoot dry matter accumulation, the plants from half metre row length of one row from each treatment were harvested and sun dried and then dried in the oven at $60^{\circ} \mathrm{C}$ to a constant weight. The initial observation was recorded at 30 DAS and subsequently at 30 days interval till harvesting and represented in $\mathrm{kg} \mathrm{ha}^{-1}$.

Root dry matter accumulation: For root dry matter accumulation, the roots from half metre row length of one row from each treatment were taken and washed under running tap water using a sieve and afterwards sun dried. Then these were dried in the oven at $60^{\circ} \mathrm{C}$ to a constant weight. The initial observation was recorded at 30 DAS and subsequently at 30 days interval till harvesting and represented in $\mathrm{kg} \mathrm{ha}^{-1}$.

Growth indices: Crop growth rate (CGR) and relative growth rate (RGR) for each specified stage were calculated using the standard equations given by Radford (1967) given below:

$\operatorname{CGR}\left(\mathrm{g} \mathrm{m}^{-2}\right.$ day $\left.^{-1}\right)=\frac{W_{2}-W_{1}}{T_{2}-T_{1}} \times \frac{1}{A}$

Where,

$\mathrm{W}_{2}=$ Dry weight of crop plant at the time interval $\mathrm{T}_{2}(\mathrm{~g})$

$\mathrm{W}_{1}=$ Dry weight of crop plant at the time interval $\mathrm{T}_{1}(\mathrm{~g})$

$$
\mathrm{A}=\text { Ground area }\left(\mathrm{m}^{2}\right)
$$

Where,

$$
\frac{\log _{e} W_{2}-\log _{e} W_{1}}{T_{2}-T_{1}}
$$

$\mathrm{W}_{2}=$ Dry weight of crop plant at the time interval $\mathrm{T}_{2}$ (g)

$\mathrm{W}_{1}=$ Dry weight of crop plant at the time interval $\mathrm{T}_{1}$ (g) 
Zorawar Singh et al. / J. Appl. \& Nat. Sci. 9 (3): 1422 -1428 (2017)

Table 1. Effect of biofertilizers and phosphorus on plant height of chickpea.

\begin{tabular}{|c|c|c|c|c|c|}
\hline \multirow[t]{2}{*}{ Treatment } & \multicolumn{5}{|c|}{ Plant height $(\mathrm{cm})$} \\
\hline & 30 DAS & 60 DAS & 90 DAS & 120 DAS & At harvest \\
\hline \multicolumn{6}{|l|}{ Biofertilizers } \\
\hline Uninoculated & 15.9 & 25.1 & 50.0 & 59.8 & 61.0 \\
\hline Mesorhizobium & 17.5 & 28.5 & 54.3 & 62.7 & 65.2 \\
\hline Mesorhizobium + RB-1 & 19.6 & 33.1 & 59.6 & 65.5 & 67.5 \\
\hline Mesorhizobium + RB-2 & 18.9 & 32.9 & 58.7 & 64.7 & 66.6 \\
\hline $\mathrm{CD}(\mathrm{p}=0.05)$ & 1.3 & 2.3 & 4.3 & 2.3 & 2.2 \\
\hline \multicolumn{6}{|l|}{$\mathrm{P}_{2} \mathrm{O}_{5}\left(\mathrm{~kg} \mathrm{ha}^{-1}\right)$} \\
\hline 0 & 16.0 & 25.4 & 49.5 & 56.9 & 57.7 \\
\hline 15 & 17.7 & 29.2 & 54.4 & 61.9 & 63.6 \\
\hline 20 & 19.0 & 32.1 & 58.7 & 66.0 & 68.6 \\
\hline 25 & 19.2 & 32.9 & 60.0 & 67.9 & 70.4 \\
\hline $\mathrm{CD}(\mathrm{p}=0.05)$ & 1.3 & 2.3 & 4.3 & 2.3 & 2.2 \\
\hline
\end{tabular}

Table 2. Effect of biofertilizers and phosphorus on primary branches of chickpea.

\begin{tabular}{|c|c|c|c|c|}
\hline \multirow[t]{2}{*}{ Treatment } & \multicolumn{4}{|c|}{ Number of primary branches plant $^{-1}$} \\
\hline & 60 DAS & 90 DAS & 120 DAS & At harvest \\
\hline \multicolumn{5}{|l|}{ Biofertilizers } \\
\hline Uninoculated & 3.1 & 4.2 & 4.4 & 4.4 \\
\hline Mesorhizobium & 3.4 & 4.7 & 4.8 & 4.8 \\
\hline Mesorhizobium + RB-1 & 3.7 & 5.4 & 5.6 & 5.6 \\
\hline Mesorhizobium + RB-2 & 3.6 & 5.2 & 5.4 & 5.4 \\
\hline $\mathrm{CD}(\mathrm{p}=0.05)$ & 0.2 & 0.4 & 0.3 & 0.3 \\
\hline \multicolumn{5}{|l|}{$\mathrm{P}_{2} \mathrm{O}_{5}\left(\mathrm{~kg} \mathrm{ha}^{-1}\right)$} \\
\hline 0 & 3.1 & 4.2 & 4.5 & 4.5 \\
\hline 15 & 3.4 & 4.7 & 5.0 & 5.0 \\
\hline 20 & 3.6 & 5.3 & 5.3 & 5.3 \\
\hline 25 & 3.7 & 5.3 & 5.3 & 5.3 \\
\hline $\mathrm{CD}(\mathrm{p}=0.05)$ & 0.2 & 0.4 & 0.3 & 0.3 \\
\hline
\end{tabular}

Table 3. Effect of biofertilizers and phosphorus on secondary branches of chickpea.

\begin{tabular}{lcccc}
\hline Treatment & \multicolumn{4}{c}{ Number of secondary branches plant ${ }^{-1}$} \\
\cline { 2 - 4 } & 60 DAS & 90 DAS & 120 DAS & At harvest \\
\hline Biofertilizers & & & & \\
Uninoculated & 8.7 & 20.2 & 22.6 & 23.4 \\
Mesorhizobium & 9.5 & 21.4 & 25.1 & 26.0 \\
Mesorhizobium + RB-1 & 10.2 & 22.8 & 26.9 & 27.8 \\
Mesorhizobium $+\mathrm{RB}-2$ & 10.2 & 22.2 & 26.3 & 1.8 \\
$\mathrm{CD}(\mathrm{p}=0.05)$ & 0.6 & 0.9 & 1.8 & 22.9 \\
$\mathrm{P}_{2} \mathrm{O}_{5}\left(\mathrm{~kg} \mathrm{ha}^{-1}\right)$ & & & \\
0 & 8.6 & 19.5 & 22.1 & 25.7 \\
15 & 9.5 & 21.4 & 24.8 & 27.6 \\
20 & 10.2 & 22.6 & 26.8 & 28.1 \\
25 & 10.3 & 23.1 & 27.2 & 1.8 \\
$\mathrm{CD}(\mathrm{p}=0.05)$ & 0.6 & 0.9 & & 1.8 \\
\hline
\end{tabular}

Table 4. Effect of biofertilizers and phosphorus on shoot dry matter accumulation of chickpea.

\begin{tabular}{|c|c|c|c|c|c|}
\hline \multirow[t]{2}{*}{ Treatment } & \multicolumn{5}{|c|}{ Shoot dry matter accumulation $\left(\mathrm{kg} \mathrm{ha}^{-1}\right)$} \\
\hline & 30 DAS & 60 DAS & 90 DAS & 120 DAS & At harvest \\
\hline \multicolumn{6}{|l|}{ Biofertilizers } \\
\hline Uninoculated & 198 & 608 & 3239 & 4506 & 5667 \\
\hline Mesorhizobium & 251 & 716 & 3536 & 4872 & 6011 \\
\hline Mesorhizobium + RB-1 & 288 & 858 & 3819 & 5267 & 6256 \\
\hline Mesorhizobium + RB-2 & 284 & 813 & 3789 & 5131 & 6173 \\
\hline $\mathrm{CD}(\mathrm{p}=0.05)$ & 23 & 58 & 244 & 362 & 313 \\
\hline \multicolumn{6}{|l|}{$\mathrm{P}_{2} \mathrm{O}_{5}\left(\mathrm{~kg} \mathrm{ha}^{-1}\right)$} \\
\hline 0 & 200 & 591 & 3008 & 4466 & 5630 \\
\hline 15 & 245 & 719 & 3525 & 4843 & 5936 \\
\hline 20 & 285 & 816 & 3850 & 5203 & 6208 \\
\hline 25 & 291 & 869 & 4000 & 5264 & 6333 \\
\hline $\mathrm{CD}(\mathrm{p}=0.05)$ & 23 & 58 & 244 & 362 & 313 \\
\hline
\end{tabular}


Table 5. Effect of biofertilizers and phosphorus on root dry matter accumulation of chickpea.

\begin{tabular}{lccccc}
\hline Treatment & \multicolumn{5}{c}{ Root dry matter accumulation $\mathbf{k g ~ h a ~}^{-\mathbf{1}}$ ) } \\
\cline { 2 - 5 } & 30 DAS & 60 DAS & 90 DAS & 120 DAS & At harvest \\
\hline Biofertilizers & 99 & 182 & 305 & 272 & 212 \\
Uninoculated & 118 & 205 & 329 & 301 & 236 \\
Mesorhizobium & 148 & 231 & 355 & 335 & 262 \\
Mesorhizobium $+\mathrm{RB}-1$ & 144 & 227 & 350 & 331 & 257 \\
Mesorhizobium $+\mathrm{RB}-2$ & 11 & 20 & 21 & 28 & 26 \\
$\mathrm{CD}(\mathrm{p}=0.05)$ & & & & \\
$\mathrm{P}_{2} \mathrm{O}_{5}\left(\mathrm{~kg} \mathrm{ha}^{-1}\right)$ & 107 & 181 & 304 & 276 & 211 \\
0 & 124 & 206 & 330 & 305 & 237 \\
15 & 137 & 228 & 351 & 328 & 258 \\
20 & 141 & 230 & 354 & 330 & 261 \\
25 & 11 & 20 & 21 & 28 & 26 \\
$\mathrm{CD}(\mathrm{p}=0.05)$ & & & & \\
\hline
\end{tabular}

Table 6. Effect of biofertilizers and phosphorus on CGR of chickpea.

\begin{tabular}{|c|c|c|c|c|}
\hline \multirow[t]{2}{*}{ Treatment } & \multicolumn{4}{|c|}{ CGR $\left(\mathrm{g} \mathrm{m}^{-2}\right.$ day $\left.^{-1}\right)$} \\
\hline & 30-60 DAS & 60-90 DAS & 90-120 DAS & 120 DAS-Harvest \\
\hline \multicolumn{5}{|l|}{ Biofertilizers } \\
\hline Uninoculated & 1.37 & 8.76 & 4.18 & 3.91 \\
\hline Mesorhizobium & 1.55 & 9.39 & 4.77 & 3.47 \\
\hline Mesorhizobium + RB-1 & 1.90 & 9.87 & 4.96 & 3.16 \\
\hline Mesorhizobium + RB-2 & 1.76 & 9.91 & 4.04 & 3.54 \\
\hline $\mathrm{CD}(\mathrm{p}=0.05)$ & 0.19 & 0.81 & NS & NS \\
\hline \multicolumn{5}{|l|}{$\mathrm{P}_{2} \mathrm{O}_{5}\left(\mathrm{~kg} \mathrm{ha}^{-1}\right)$} \\
\hline 0 & 1.30 & 8.06 & 5.02 & 3.72 \\
\hline 15 & 1.58 & 9.35 & 4.69 & 3.34 \\
\hline 20 & 1.77 & 10.11 & 4.44 & 3.42 \\
\hline 25 & 1.93 & 10.43 & 4.17 & 3.59 \\
\hline $\mathrm{CD}(\mathrm{p}=0.05)$ & 0.19 & 0.81 & NS & NS \\
\hline
\end{tabular}

Table 7. Effect of biofertilizers and phosphorus on RGR of chickpea.

\begin{tabular}{|c|c|c|c|c|}
\hline \multirow[t]{2}{*}{ Treatment } & \multicolumn{4}{|c|}{ RGR $\left(\mathrm{g} \mathrm{g}^{-1} \mathrm{day}^{-1}\right)$} \\
\hline & 30-60 DAS & 60-90 DAS & 90-120 DAS & 120 DAS- harvest \\
\hline \multicolumn{5}{|l|}{ Biofertilizers } \\
\hline Uninoculated & 0.016 & 0.024 & 0.005 & 0.003 \\
\hline Mesorhizobium & 0.015 & 0.023 & 0.005 & 0.003 \\
\hline Mesorhizobium + RB-1 & 0.016 & 0.022 & 0.005 & 0.002 \\
\hline Mesorhizobium + RB-2 & 0.015 & 0.022 & 0.004 & 0.003 \\
\hline $\mathrm{CD}(\mathrm{p}=0.05)$ & NS & 0.001 & NS & NS \\
\hline \multicolumn{5}{|l|}{$\mathrm{P}_{2} \mathrm{O}_{5}\left(\mathrm{~kg} \mathrm{ha}^{-1}\right)$} \\
\hline 0 & 0.016 & 0.024 & 0.006 & 0.003 \\
\hline 15 & 0.016 & 0.023 & 0.005 & 0.003 \\
\hline 20 & 0.015 & 0.023 & 0.004 & 0.003 \\
\hline 25 & 0.016 & 0.022 & 0.004 & 0.003 \\
\hline $\mathrm{CD}(\mathrm{p}=0.05)$ & NS & NS & NS & NS \\
\hline
\end{tabular}

The data were subjected to analysis of variance as per CPCS 1 software developed by Department of Statistics, Punjab Agricultural University, Ludhiana (Cheema and Singh, 1991) and the mean values were compared at 0.05 probability level.

\section{RESULTS AND DISCUSSION}

Plant biometery:

Plant height: The plant height was significantly affected by both microbial treatments as well as P levels (Table 1). At 30 DAS, the highest plant height was observed with Mesorhizobium + RB-1 (19.6 cm) which was statistically at par with Mesorhizobium +
RB-2 $(18.9 \mathrm{~cm})$ and significantly higher than control $(15.9 \mathrm{~cm})$ and sole treatment of Mesorhizobium (17.5 $\mathrm{cm})$. This improvement in plant height may be attributed to phytohormone IAA production by PGPR strains (Pseudomonas sp. and Bacillus sp.) which plays a major role in regulation of plant development. Kaur et al. (2015) also reported improvement in plant height in consortium treatments as compared to sole treatment and control. Similar trend was observed at 60 and 90 DAS. Further, at all the sampling stages, the periodic plant height was found to be highest with $25 \mathrm{~kg} \mathrm{P}_{2} \mathrm{O}_{5}$ $\mathrm{ha}^{-1}$ which was statistically at par with $20 \mathrm{~kg} \mathrm{P}_{2} \mathrm{O}_{5} \mathrm{ha}^{-1}$ but significantly higher than 0 and $15 \mathrm{~kg} \mathrm{P}_{2} \mathrm{O}_{5} \mathrm{ha}^{-1}$. 
The increase in the height at decreasing rate was found after 90 DAS. Increment in plant height might be due to improved biological activities in the presence of balanced supply of phosphorus. These results are in agreement with the findings of other researchers (Basir et al., 2008, Gulpadiya et al., 2014).

Number of branches: At different intervals, the coinoculation with Mesorhizobium and RB-1 produced highest number of primary branches plant ${ }^{-1}$ which was statistically at par with Mesorhizobium + RB-2 but significantly higher than individual inoculation of Mesorhizobium and control (Table 2). Similar trend was observed in number of secondary branches plant ${ }^{-1}$ except at 120 DAS and at harvest where number of secondary branches with Mesorhizobium + RB-1 was at par with sole inoculation of Mesorhizobium (Table 3). Such improvement in number of branches plant ${ }^{-1}$ might be related to the microbial production of phytohormones which cause changes in root morphology and physiology, resulting in increased nutrient uptake from soil which results in better growth and development of plants (Sharma et al., 2013). As compared to unfertilized control, differential levels of phosphorus dose produced higher number of primary and secondary branches plant ${ }^{-1}$ at different periods of observation. At 60 and $90 \mathrm{DAS}$, application of $25 \mathrm{~kg} \mathrm{P}_{2} \mathrm{O}_{5} \mathrm{ha}^{-1}$ gave significantly higher number of primary branches plant ${ }^{1}$ than 0 and $15 \mathrm{~kg} \mathrm{P}_{2} \mathrm{O}_{5}$ ha $^{-1}$ while it was at par with 20 $\mathrm{kg} \mathrm{P}_{2} \mathrm{O}_{5} \mathrm{ha}^{-1}$. At 120 DAS and at harvest, 15, 20 and 25 $\mathrm{kg} \mathrm{P}_{2} \mathrm{O}_{5}$ ha $^{-1}$ were at par in primary branches plant ${ }^{-1}$. Furthermore, no increment in the number of primary branches was observed after 120 days of sowing. At all the periods of observations, application of $25 \mathrm{~kg} \mathrm{P}_{2} \mathrm{O}_{5}$ $\mathrm{ha}^{-1}$ recorded significantly higher number of secondary branches plant ${ }^{-1}$ than 0 and $15 \mathrm{~kg} \mathrm{P}_{2} \mathrm{O}_{5}$ ha $^{-1}$ but at par with $20 \mathrm{~kg} \mathrm{P}_{2} \mathrm{O}_{5} \mathrm{ha}^{-1}$ (Table 3 ). The progressive increase in number of branches might be attributed to the role of phosphorus in better root development and proliferation, nodules formation and $\mathrm{N}_{2}$ fixation by supplying assimilates to the roots. These results are in agreement with those of Das et al., (2013) who also reported improvement in number of branches plant ${ }^{-1}$ with incremental doses of phosphorus from 15 to $45 \mathrm{~kg}$ $\mathrm{P}_{2} \mathrm{O}_{5} \mathrm{ha}^{-1}$ in chickpea.

Shoot dry matter accumulation: At all sampling stages, the lowest shoot dry matter accumulation (SDMA) was recorded in control (Table 4). At 30 DAS, coinoculation of Mesorhizobium + RB-1 gave maximum SDMA which was found to be significantly higher than Mesorhizobium only and control. Similar trend was observed at 60,90 and 120 DAS but not at harvest where Mesorhizobium + RB-1 and Mesorhizobium were statistically at par with each other. However, dual inoculation of Mesorhizobium + RB-2 produced statistically similar shoot dry weight as with Mesorhizobium + RB-1 at all the growth stages. The higher SDMA with dual inoculations may be attribut- ed to the favourable synergistic effect of Mesorhizobium and PGPRs on plant growth through phosphate solubilisation and IAA and siderophore production. These results are in close proximity with those of Verma et al. (2013). Further, application of phosphorus showed a significant increase in SDMA at different periods of observations. At $30 \mathrm{DAS}$, highest SDMA was recorded with $25 \mathrm{~kg} \mathrm{P}_{2} \mathrm{O}_{5} \mathrm{ha}^{-1}$ which was significantly higher than 0 and $15 \mathrm{~kg} \mathrm{P}_{2} \mathrm{O}_{5} \mathrm{ha}^{-1}$ and at par with $20 \mathrm{~kg} \mathrm{P} \mathrm{O}_{5} \mathrm{ha}^{-1}$. The data regarding SDMA followed the similar trend at 60,90 and 120 DAS and at harvest. Similar results were reported by Gulpadiya and Chhonkar (2014) who revealed that growth parameters of chickpea viz. plant height $(45.85 \mathrm{~cm})$, dry matter (15.28 g plant $^{-1}$ ) and number of branches plant ${ }^{-1}$ (4.4) increased significantly with incremental levels of phosphorus from 0 to $90 \mathrm{~kg} \mathrm{P} \mathrm{ha}{ }^{-1}$.

Root dry matter accumulation (RDMA): Dual inoculation of Mesorhizobium + RB-1 and Mesorhizobium + RB-2 produced statistically similar root dry matter and both were significantly better than Mesorhizobium only and control at all the sampling stages i.e. 30, 60, 90 and 120 DAS except at harvest where Mesorhizobium only produced statistically similar root dry weight as compared to Mesorhizobi$u m+\mathrm{RB}-2$. These results cognate with those of Verma et al. (2013) who also reported that dual inoculation of Rhizobium sp. and Pseudomonas fluorescens as well as Rhizobium sp. and Bacillus megaterium gave significantly higher root dry weight in contrast to sole inoculation and control. The improvement in the RDMA might be attributed to synergistic effect of microbial inoculants on the root proliferation. At 30 DAS, application of $25 \mathrm{~kg} \mathrm{P}_{2} \mathrm{O}_{5} \mathrm{ha}^{-1}$ gave highest root dry weight which was significantly higher than 0 and $15 \mathrm{~kg} \mathrm{P}_{2} \mathrm{O}_{5} \mathrm{ha}^{-1}$ and at par with $20 \mathrm{~kg} \mathrm{P}_{2} \mathrm{O}_{5} \mathrm{ha}^{-1}$ (Table 5). Similar trend was observed at 60 and 90 DAS. However, at 120 DAS and at harvest, 15, 20 and $25 \mathrm{~kg} \mathrm{P}_{2} \mathrm{O}_{5} \mathrm{ha}^{-1}$ were at par in RDMA. The improvement in RDMA with phosphorus application may be attributed to essential role of phosphorus in the root development. Gulpadiya and Chhonkar (2014) also reported significant improvement in root weight with incremental dose of phosphorus from 0 to $60 \mathrm{~kg} \mathrm{P}$ $\mathrm{ha}^{-1}$.

\section{Growth indices}

Crop growth rate: Starting from the lower value, CGR reached a certain peak and then declined at the later stages; highest value of CGR was observed at 6090 DAS (Table 6). The lower value of the CGR during the initial stages of growth might be due to slower growth of chickpea during the early stage and sudden increase in the growth during the period of 60-90 DAS resulted in higher CGR value, which might be due to conducive environmental conditions for chickpea growth. There was a variable trend in its values at different periods of observation in all the treatments and 
significant changes with respect to biofertilizer treatments as well as phosphorus were observed at 30-60 and 60-90 DAS. The lowest value of CGR was observed in uninoculated and unfertilized control. During 30-60 DAS, the peak value of CGR was observed with Mesorhizobium + RB-1 which was significantly higher than control and Mesorhizobium only but at par with Mesorhizobium + RB-2 which might be attributed to better root and shoot development in the respective treatments (Table 4 and 5). However, during 60-90 DAS highest value of CGR was realized with Mesorhizobium + RB-1 which was found to be at par with Mesorhizobium only and Mesorhizobium + RB-2 but significantly higher than control. After that a sudden decline in the CGR was observed during the subsequent intervals of growth. As per the $P$ levels, during 30-60 and 60-90 DAS, the peak value of CGR was observed with $25 \mathrm{~kg}$ $\mathrm{P}_{2} \mathrm{O}_{5}$ ha $^{-1}$ which was significantly higher than 0 and $15 \mathrm{~kg} \mathrm{P}_{2} \mathrm{O}_{5} \mathrm{ha}^{-1}$ but at par with $20 \mathrm{~kg} \mathrm{P}_{2} \mathrm{O}_{5} \mathrm{ha}^{-1}$ which might be attributed to better growth and development of plants with incremental levels of phosphorus. However, decline in the CGR values was observed after 90 DAS and treatments showed nonsignificant effect.

Relative growth rate: The relative growth rate showed variable trend in its values at different periods of observation in all the treatments and significant changes with respect to biofertilizer treatments were observed at 60-90 DAS (Table 7). During the initial stages of the crop growth the ratio between alive and dead tissues is high and almost the entire cells of productive organs are actively engaged in vegetative matter production. The results exhibited declining trend in RGR values with the advancement of the crop age after 90 DAS. Similar results were reported by Namvar et al., (2011) who noticed decline in the RGR value as the crop ages in chickpea which may be due to the fact that, with the ageing of the crop, the metabolic activity of tissues decreases and hence these tissues cannot contribute to the growth of the crop. Kour et al., (2016) also reported decline in the RGR value which may be attributed to increase in the dead and woody tissue as compared to alive tissue towards the maturity of crop.

\section{Conclusion}

The findings of this study indicate that application of microbial inoculants and phosphorus levels have pronounced effect on the growth attributes viz. plant height, number of primary and secondary branches, root and shoot dry matter accumulation as well as on growth indice sat different growth stages. Application of $20 \mathrm{~kg} \mathrm{P}_{2} \mathrm{O}_{5} \mathrm{ha}^{-1}$ was found to be the appropriate dose and Mesorhizobium + RB-1 was superior among the biofertilizer treatments. The dual inoculation with PGPR strains along with phosphorus application has a supplementary effect on the growth and development of chickpea.

\section{ACKNOWLEDGEMENTS}

The authors are thankful to Punjab Agricultural University, Ludhiana for providing the infrastructure required to conduct the experiment. Furthermore, the authors are also thankful to Dr. Poonam Sharma, Senior Microbiologist, Department of Plant Breeding \& Genetics, PAU, Ludhiana for providing biofertilizer strains for these studies.

\section{REFERENCES}

Anonymous (2016). Area, production and productivity of gram in India. http://www.indiastat.com/.

Basir, A., Shah, Z., Naeem, M., Bakht, J. and Khan, Z.H. (2008). Effect of phosphorus and farm yard manure on agronomic traits of chickpea (Cicer arietinum L.). Sarhad J. Agri. 24:567-72.

Cheema, H.S. and Singh, B. (1991). Software Statstical CPCS-1. Department of Statistics, Punjab Agricultural University, Ludhiana, India.

Das, S., Pareek, B.L., Kumawat, A. and Dhikwal, S.R. (2013). Effect of phosphorus and biofertilizers on productivity of chickpea (Cicer arietinum L.) in north western Rajasthan, India. Legume Res. 38: 511-14.

Dotaniya, M.L., Pingoliya, K.K., Lata, M., Verma, R., Regar, K.L., Deewan, P. and Dotaniya, C.K. (2014). Role of phosphorus in chickpea production. African J. Agric. Res. 9: 3736-3743

Gulpadiya, V.K. and Chhonkar, D.S. (2014). Effect of phosphorus on growth, productivity and economics of chickpea varieties. Annals Plant Soil Res. 16: 334-37.

Gulpadiya, V.K., Singh, B.P., Chhonkar, D.S., and Gupta, D. (2014). Effect of varieties and phosphorus levels on growth and yield of chickpea (Cicer arietinum L.). $J$. Rural Agril. Res. 14: 43-44.

Hirdyani, H. (2014). Nutritional composition of chickpea (Cicer arietinum L.) and value added products. Indian J. Comm. Health 26: 102-06.

Kandoliya, U.K. and Vakharia, D.N. (2013). Antagonistic effect of Pseudomonas fluorescens against Fusarium oxysporum f.sp. cicero causing wilt in chickpea. Legume Res. 36: 569-75.

Kaur, N. and Sharma, P. (2013). Screening and characterization of native Pseudomonas sp. as plant growth promoting rhizobacteria in chickpea (Cicer arietinum L.) rhizospere. Afr. J. Microbiol. Res .7: 1465-74.

Kaur, N., Sharma, P. and Sharma, S. (2015). Co-inoculation of Mesorhizobium sp. and plant growth promoting rhizobacteria Pseudomonas sp. as bio-enhancer and biofertilizer in chickpea (Cicer arietinum L.). Legume Res. 38: 367-74.

Kour, R., Sharma, B.C., Kumar, A., Kour, P. and Nandan, B. (2016). Study of physiological growth indices in chickpea (Cicer arietinum) + mustard (Brassica juncea) intercropping system under different weed management practices. Legume Res. 39: 453-58.

Namvar, A., Sharifi, R.S. and Khandan, T. (2011). Growth analysis and yield of chickpea (Cicer arietinum L.) in relation to organic and organic nitrogen fertilization. Ekologija, 57: 97-108. 
Pingoliya, K.K., Mathur, A.K., Dotaniya, M.L., Jajoria, D.K. and Narolia, G.P. (2014). Effect of phosphorus and iron levels on growth and yield attributes of chickpea (Cicer arietinum L.) under agroclimatic zone IV a of Rajasthan, India. Legume Res. 37: 537-41.

Radford, P. J. (1967). Growth analysis formulae-their use and abuse. Crop Sci. 3: 171-176.

Sarawgi, S.K., Chitale, S., Tiwari, A. and Singh, S. (2012). Effect of phosphorus application alongwith PSB, Rhizobium and VAM on P fractionation and productivity of soybean (Glycine max). Indian J.Agron. 57: 55-60.

Shahzad, S.M., Khalid, A., Arif, M.S., Riaz, M., Ashraf, M., Iqbal, Z. and Yasmeen, T. (2014). Co-inoculation integrated with $\mathrm{P}$-enriched compost improved nodulation and growth of chickpea (Cicer arietinum L.) under irrigated and rainfed farming systems. Biol. Fertil. Soils 50: 1-12.
Sharma, P., Khanna, V., Kaur, N., Dhillon, G., Singh, G., Sharma, S., Kaur, H. and Saxena, A.K. (2013). Effect of dual inoculation of Pseudomonas argentinensis LPGPR1 and Mesorhizobium on growth of chickpea (Cicer arietinum L.). J. Res. Punjab Agril. Univ. 50: 1-4.

Singh, U. and Singh, B. (2014). Effect of basal and foliar application of diammonium phosphate in cognizance with phosphate-solubilizing bacteria on growth, yield and quality of rainfed chickpea (Cicer arietinum L.). Indian J.Agron. 59: 427-32.

Verma, J.P.,Yadav, J., Tiwari, K.N. and Kumar, A. (2013). Effect of indigenous Mesorhizobium sp. and plant growth promoting rhizobacteria on yield and nutrient uptake of chickpea (Cicer arietinum L.). Ecol.Engg. 51: 282-86. 